\title{
SACRIFÍCIO RITUAL E CRUELDADE CONTRA ANIMAIS: UM CASO DE SUSTENTABILIDADE CULTURAL
}

\author{
Walter Claudius Rothenburg ${ }^{1}$ \\ Centro de Pós-Graduação da Instituição Toledo de Ensino (ITE-Bauru) \\ Tatiana Stroppa ${ }^{2}$ \\ Centro de Pós-Graduação da Instituição Toledo de Ensino (ITE-Bauru)
}

\section{RESUMO}

O sacrifício de animais em rituais insere-se problematicamente no âmbito de proteção da liberdade religiosa, pois suscita a preocupação ecológica com o bem-estar dos animais, uma vez que a Constituição brasileira veda práticas que submetam os animais à crueldade. As leis que proíbem o sacrifício ritualístico de animais atingem, sobretudo, práticas adotadas por grupos religiosos de matriz africana, de forte composição negra, numa manifestação de discriminação não apenas religiosa, mas também racial. O Supremo Tribunal Federal verificou a inconstitucionalidade dessas leis por meio do Recurso Extraordinário 494.601/RS, tendo utilizado o critério da proporcionalidade, num contexto multicultural e de laicidade estatal. A metodologia utilizada neste artigo consiste no exame de caso concreto (análise jurisprudencial), a partir de uma abordagem indutiva, conduzida com base na teoria dos direitos fundamentais (pesquisa bibliográfica) e com referência em experiências estrangeiras (análise comparativa). $\mathrm{O}$ resultado da reflexão aponta para o acerto da ponderação realizada pelo Supremo Tribunal Federal ao validar a legislação que permite o sacrifício ritualístico de animais. Conclui-se que a proteção da liberdade religiosa não pode, contudo, desconsiderar a proibição constitucional de tratar animais com crueldade.

1 Livre-docente em Direitos Humanos pela Universidade de São Paulo (USP). Doutor em Direito do Estado e Mestre em Direito Público pela Universidade Federal do Paraná (UFPR). Pós-graduado em Direito Constitucional pela Universidade de Paris II. Graduado em Direito pela UFPR. Docente do ITE-Bauru. ORCID: https://orcid.org/0000-0003-3422-3846 / e-mail: wcrburg@gmail.com

2 Doutoranda em Direito pelo ITE-Bauru. Mestre em Direito pelo ITE-Bauru. Graduada em Direito pelo ITE-Bauru. Professora de Direito Constitucional e Direito Processual Constitucional no Centro Universitário de Bauru (CEUB) - ITE e na Faculdade Iteana de Botucatu (FITB). ORCID: https:// orcid.org/0000-0002-3456-7588 / e-mail: tatianastroppa@hotmail.com 
Palavras-chave: crueldade; doutrina da ponderação; liberdade religiosa; sacrifício de animais; sustentabilidade cultural.

\title{
SACRIFICE RITUALS AND CRUELTY TO ANIMALS: A CASE OF CULTURAL SUSTAINABILITY
}

\begin{abstract}
Animal sacrifice in rituals faces problems in the scope of the right to religious freedom, since it raises the ecological concern with the well-being of animals, once the Brazilian Constitution prohibits practices that subject animals to cruelty. The laws that prohibit animal sacrifice rituals affect, above all, the practices adopted by African religious communities. Such communities are mainly composed of black people, in a demonstration of not only religious discrimination but also racial. The Federal Supreme Court verified the unconstitutionality of these laws through Extraordinary Appeal 494.601 / RS, using the criterion of proportionality in a multicultural and state secular context. The methodology used in this paper consists of a concrete case study (jurisprudential analysis), based on an inductive approach and the theory of fundamental rights (bibliographic research), with reference to foreign experiences (comparative analysis). The result of the reflection points to the correctness of the consideration made by the Federal Supreme Court in validating the legislation that allows the ritualistic sacrifice of animals. Yet, the protection of religious freedom may not disregard the constitutional prohibition of treating animals with cruelty.
\end{abstract}

Keywords: animal sacrifice rituals; balancing doctrine; cruelty; cultural sustainability; religious freedom. 


\section{INTRODUÇÃO}

O sacrifício ritual de animais conhece nos argumentos ambientalistas uma importante objeção, que assume foros constitucionais diante da proibição constante do art. 225, § 1º , VII, da Constituição Federal de 1988. Com supedâneo nessa preocupação com o bem-estar dos animais, são promulgadas leis que pretendem proibir o sacrifício, como é o caso do Código Estadual de Proteção aos Animais do Rio Grande do Sul (Lei Estadual n. 11.915/2003, modificada pela Lei n. 12.131/2004) e da Lei n. 1.960/2016 do Município de Cotia (SP). O sacrifício religioso de animais constitui uma forma de manifestação da liberdade religiosa e, assim, em que medida tal prática, inserida no âmbito normativo da liberdade religiosa, pode ser restringida em função da proteção aos animais?

No atual contexto brasileiro, outro aspecto merece ainda ser considerado. $\mathrm{O}$ abate ritual de animais é praticado sobretudo por religiões de matriz africana, que são historicamente perseguidas pelos grupos dominantes, inclusive pelas religiões tradicionais cristãs. Esse preconceito religioso tem um inegável componente de discriminação étnica: são religiões predominantemente de brancos que perseguem religiões predominantemente de negros. Assim, o conflito constitucional envolve a questão da liberdade e da igualdade em um ambiente social marcado pela pluralidade.

Afinal, o sacrifício de animais constitui uma forma de liturgia protegida pela liberdade religiosa assegurada constitucionalmente? E, sendo positiva a resposta, é possível que tal prática seja regulada pelo Estado?

Essa discussão chegou ao Supremo Tribunal Federal em meados de 2018, pela via do Recurso Extraordinário 494.601/RS, e apresentou um caso de colisão de direitos constitucionais enfrentado com a técnica usual da ponderação (critério da proporcionalidade). No julgamento desse recurso em que se discutia a validade da Lei Estadual n. 12.131/2004, o STF entendeu, por maioria de votos, que a lei do Rio Grande do Sul que permite o sacrifício de animais em ritos religiosos é compatível com a Constituição. No sopesamento dos diversos direitos implicados - desde a liberdade religiosa à proibição da crueldade contra os animais - importa destacar a proscrição à discriminação racial ou étnica associada às manifestações religiosas de afro-brasileiras.

Utiliza-se uma abordagem indutiva, a partir do exame de caso concreto (análise jurisprudencial), no contexto da teoria dos direitos fundamentais (pesquisa bibliográfica) e em comparação a experiências estrangeiras. 


\section{O SUPREMO TRIBUNAL FEDERAL BRASILEIRO ENFRENTA A QUESTÃO}

O Código Estadual de Proteção aos Animais do Rio Grande do Sul (Lei Estadual n. 11.915/2003, com as alterações da Lei n. 12.131/2004) dispõe que é vedado causar sofrimento ou abusar de animais, mas que não se enquadra nas vedações o livre exercício dos cultos e liturgias das religiões de matriz africana (art. $2^{\circ}$, parágrafo único).

Foi proposta perante o Tribunal de Justiça gaúcho a ação direta de inconstitucionalidade n. 70010129690(TJE) em face desse dispositivo, e a demanda foi julgada improcedente. Dessa decisão foi interposto o Recurso Extraordinário 494.601/RS (relator originário Min. Marco Aurélio e redator do acórdão Min. Edson Fachin), que agitou o conflito entre o direito fundamental de liberdade religiosa (Constituição da República, art. $5^{\circ}, \mathrm{VI}$ ); a igualdade, sem discriminações de qualquer natureza (CR, art. $3^{\circ}$, IV, e art. $5^{\circ}$, caput e XLI); o direito fundamental de identidade cultural (CR, art. $\left.215, \S 1^{\circ}\right)$; o princípio da laicidade do Estado $(\mathrm{CR}$, art. $19, \mathrm{I})$ e a proibição de submissão dos animais à crueldade (CR, art. 225, § 1 $\left.1^{\circ}, \mathrm{VII}\right)$.

A cuidadosa análise do presente caso feita na origem pelo Tribunal de Justiça gaúcho representa valioso precedente (RIO GRANDE DO SUL, 2005). A gênese da legislação local (Código Estadual de Proteção aos Animais) revela que, justamente por temer-se que a previsão genérica de vedação à crueldade e ao abuso de animais, contida na versão original (Lei 11.915/2003), inibisse os rituais de religiões afro-brasileiras, foi apresentado um projeto de lei (PL 282/2003) para permitir o sacrifício ritualístico, incluindo-se, então, um parágrafo único ao art. $2^{\circ}$. O projeto foi aprovado pela quase totalidade dos deputados estaduais (ORO; CARVALHO; SCURO, 2017). Portanto, sob o princípio do Estado Democrático de Direito, deve ser ressaltada a atuação corretiva do próprio Poder Legislativo em prol do direito fundamental de crença e da manifestação cultural afro-brasileira.

O Tribunal de Justiça do Rio Grande do Sul reconheceu a pertinência da lei estadual ao rejeitar a alegação de inconstitucionalidade, afastando os argumentos de invasão em matéria penal (de competência legislativa federal), de afronta ao princípio da igualdade e ao caráter laico do Estado brasileiro.

Sem a complementação legislativa que fora impugnada (e que autoriza o sacrifício ritual de animais), a vedação legal geral, ao invés de enfatizar o princípio da liberdade religiosa, produz "o efeito perverso de deixar sob 
suspeita o exercício de culto de natureza sacrificial, independentemente de sua matriz" (BRASIL, 2007).

O Recurso Extraordinário (RE) 494.601/RS foi julgado em 28 de março de 2019 e, por maioria de votos, o STF entendeu que a lei do Rio Grande do Sul que permite o sacrifício de animais em ritos religiosos é compatível com a Constituição, tendo fixado a seguinte tese: "É constitucional a lei de proteção animal que, a fim de resguardar a liberdade religiosa, permite o sacrifício ritual de animais em cultos de religiões de matriz africana" (BRASIL, 2019).

A tese jurídica fixada deverá ser aplicada ${ }^{3}$, por exemplo, à Lei n. 1.960/2016 do Município de Cotia (SP), que proibiu generalizadamente a "utilização, mutilação e/ou o sacrifício de animais em rituais religiosos ou de qualquer natureza", sem qualquer dispositivo que excepcione "o livre exercício dos cultos e liturgias das religiões de matriz africana", ao contrário da lei gaúcha (Lei Estadual n. 11.915/2003). Aliás, o Tribunal de Justiça de São Paulo, em sintonia com seu homólogo do sul, já julgou a lei municipal inconstitucional por ampla maioria (SÃO PAULO, 2017). ${ }^{4} \mathrm{~A}$ Corte local, na ponderação que efetuou, percebeu com acuidade a discriminação concernente às religiões afro-brasileiras, para as quais o sacrifício ritualístico de animais é essencial, ao contrário de manifestações litúrgicas de religiões poderosas e eventualmente majoritárias. Eis o resultado preciso da ponderação, segundo a ementa: "Prevalência da proteção ao livre exercício dos cultos religiosos, uma vez que a utilização de animais nessas circunstâncias não teria proporção suficiente para colocar em risco a existência equilibrada do meio ambiente". Em face desse acórdão foi interposto o RE 1.096.915/SP (rel. Min. Celso de Mello), sobrestado para aguardar o julgamento do RE 494.601/RS. ${ }^{5}$

3 Cf. o art. 987, $\S 2^{\circ}$, do Código de Processo Civil (BRASIL, 2015): “Art. 987. Do julgamento do mérito do incidente caberá recurso extraordinário ou especial, conforme o caso $[\ldots] \S 2^{\circ}$ Apreciado o mérito do recurso, a tese jurídica adotada pelo Supremo Tribunal Federal ou pelo Superior Tribunal de Justiça será aplicada no território nacional a todos os processos individuais ou coletivos que versem sobre idêntica questão de direito".

4 Cite-se, também, a Lei n. 4.977, de 27 de outubro de 2015, do município de Tatuí, que também traz uma vedação generalizada de sacrifício, nos seguintes termos: "Art. $1^{\circ}$ Fica proibida, no Município de Tatuí, a utilização, mutilação e/ou sacrifício de animais em rituais ou cultos, realizados em estabelecimentos fechados e/ou logradouros públicos, que tenham aqueles, finalidade mística, iniciática, esotérica ou religiosa, assim como em prática de seitas, religiões ou de congregações de qualquer natureza" (TATUî, 2015).

5 Apesar de já ter ocorrido o julgado do RE 494.601/RS com a respectiva fixação da tese já citada, o RE n. 1.096.915/SP ainda não foi julgado. 


\section{LIBERDADE RELIGIOSA, MINORIAS E DISCRIMINAÇÃO}

Enquanto direito subjetivo, a liberdade religiosa permite a autodeterminação garantida face à interferência do Estado e de eventuais outros atores privados, de modo a possibilitar a formação e o exercício confessional no âmbito das comunidades de fé. A faceta negativa da liberdade religiosa afirma o respeito às escolhas íntimas de crença em divindades ou no sobrenatural e, consequentemente, a possibilidade de agir de acordo com os princípios e visões correspondentes, o que caracteriza a esfera externa de exercício dos cultos religiosos (OLIVEIRA, 2010). Nesse ponto, Jónatas Machado (1996) destaca que, embora as condutas e práticas religiosas envolvam maiores problemas que as crenças em si, a leitura do direito à liberdade religiosa deve fazer com que ela corresponda a "uma unidade incindível entre as convicções e as práticas religiosas".

Deve haver, assim, um afastamento do Estado que se pretenda laico (CR, art. 19, I). Decorrência desse dever de abstenção é a vedação a práticas discriminatórias, de modo a evitar que a atuação do Estado venha a penalizar ou privilegiar alguma crença em especial (MOREIRA, 2013). Marca-se uma base de liberdade e igualdade para que os indivíduos e grupos possam viver de acordo com sua religiosidade.

Mas o que se passa no domínio privado de cada religião, guiada por preceitos dogmáticos que podem levar à distinção entre crentes e infiéis afinal, "[a] certeza da própria verdade sempre colocou em desvantagens as verdades de outros" (TEIXEIRA, 2015) -, não pode ser transposto para a esfera pública. O Estado tem deveres de imparcialidade e de neutralidade que o impedem "de estabelecer obrigações públicas de natureza religiosa" (MOREIRA, 2013, p. 644) e de tomar decisões com fundamento em dogmas religiosos.

Com efeito, a ideia de liberdade religiosa está atrelada ao reconhecimento do pluralismo (MOREIRA, 2013), inscrito na Constituição de 1988 logo em seu preâmbulo. Esse respeito pela pluralidade das expressões religiosas, e também por aquelas que revelam ausência de crença religiosa, encontra respaldo constitucional, por exemplo, na possibilidade de escusa de consciência $\left(\mathrm{CR}\right.$, art. $\left.5^{\circ}, \mathrm{VIII}\right)$ e no dever de impessoalidade imposto à administração pública (CR, art. 37, caput).

A Declaração sobre a Eliminação de Todas as Formas de Intolerância e Discriminação Fundadas na Religião ou nas Convicções, proclamada pela Assembleia Geral das Nações Unidas em 25 de novembro de 1981, 
reconhece a importância do respeito à liberdade religiosa para a paz mundial e a justiça social, bem como para a eliminação das ideologias ou práticas do colonialismo e da discriminação racial. Em seguida, a Declaração determina que os Estados se esforcem para promulgar ou derrogar leis, conforme o caso, a fim de proibir toda discriminação religiosa e tomar todas as medidas adequadas para combater a intolerância por motivo religioso (art. $4^{\circ}, \S 2^{\circ}$ ). Assim, "a inclusão dos seguidores das religiões minoritárias, mais do que gerar o sectarismo religioso, fará com que os mesmos possam exercer seus direitos sem abrir mão de suas convicções religiosas" (BREGA FILHO; ALVES, 2009, p. 91-92).

Apesar das referidas diretrizes, Heiner Bielefeldt (2016), ao apresentar relatório sobre a liberdade de religião para a Organização das Nações Unidas, afirmou que, costumeiramente, os Estados alegam que, como qualquer direito fundamental, a liberdade de religião não é absoluta, o que pode tornar-se pretexto para, sob os signos da "segurança", "ordem" e "interesses morais", refrear críticas religiosas, discriminar minorias, estreitar o controle sobre a vida da comunidade religiosa. ${ }^{6}$

A densificação da liberdade religiosa deve ter em conta o respeito às minorias religiosas e às suas estruturas organizativas e práticas litúrgicas. Justamente tendo em conta essa proteção associativa e institucional, o Tribunal Constitucional Federal Alemão julgou procedente, por maioria, uma reclamação constitucional (BverFGE 93,1) para reconhecer indevida a colocação de uma cruz ou crucifixo nas salas de aula de escola pública de ensino obrigatório não confessional, tendo estabelecido que "a liberdade de crença garante, especialmente, a participação em atos litúrgicos que uma crença prescreve ou na qual encontra expressão. A isso corresponde, no sentido oposto, a liberdade para não participar de atos litúrgicos de crença não compartilhada".

Nessa linha, o Min. Ricardo Lewandowski, do Supremo Tribunal Federal, ao votar pela improcedência da ADI 4.439/DF (proposta com o objetivo de fixar que o ensino religioso, de matrícula facultativa, previsto na Constituição, não poderia ter caráter confessional), assentou que o ensino religioso em escolas públicas pode, sim, ter natureza confessional e

6 The Special Rapporteur has often heard statements by government representatives that freedom of religion or belief, like any other right, "cannot be absolute" and sometimes must be limited in its application. This is a truism and indeed a dangerous one, since the general invocation of limitations can easily become a pretext for imposing far-reaching or arbitrary restrictions. Many Governments actually refer to broad and unspecified "security", "order" or "morality" interests in order to curb religious criticism, discriminate against minorities, tighten control over independent religious community life $[\ldots] "$. 
interconfessional, e que o conceito de laicidade no Brasil está calcado em um "tripé tolerância, igualdade e liberdade religiosa. Trata-se, acima de tudo, de um princípio constitucional voltado à proteção das minorias que, graças à separação entre o Estado e a Igreja, não podem ser obrigadas a submeter-se aos preceitos da religião majoritária" (BRASIL, 2017).

Contudo, o reconhecimento constitucional da pluralidade de formas de religiosidade "vivencia, ainda, um não desabrochar pleno das possibilidades" (VIDA, 2007, p. 296). Há uma tradição discriminatória contra as religiões de matriz africana que remonta aos primeiros registros feitos quando da trazida de africanos escravizados para o Brasil, com regulamentos que interditaram, desde o início, os batuques e as práticas litúrgicas de manifestações de espiritualidade e de ligação com a dimensão divina (VIDA, 2007).

No Brasil, as religiões afro-brasileiras ainda formam um segmento vulnerável e oprimido ${ }^{7}$ em face das religiões hegemônicas e qualificam-se como merecedoras de proteção e promoção jurídica, ainda mais diante do crescimento de grupos religiosos evangélicos e neopentecostalistas que têm construído um proselitismo propagandista - empreendido "uma verdadeira cruzada", na expressão de Teixeira (2015) - com base em mensagens fortemente depreciativas das religiões de matriz africana, apresentadas como "o reduto de demônios e condenados".

Somando à previsão geral de liberdade religiosa, o Estatuto da Igualdade Racial (Lei 12.288/2010), em seus artigos 23 a 26, traz proteção à liberdade de consciência e de crença e ao livre exercício dos cultos religiosos de matriz africana, compreendendo a proteção a seus locais de culto e a suas liturgias, o combate às práticas de intolerância religiosa, dentre outras garantias. "O Estatuto, portanto, vai além do texto constitucional, pois oferece proteção específica aos religiosos de matriz africana, do que resulta também a proteção da identidade étnica dessa população" (COELHO; OLIVEIRA; LIMA, 2016, p. 56).

Dentre o conjunto de práticas de culto afrorreligioso, destaca-se o sacrifício de animais, também denominado de imolação ou sacralização. "Especialmente para as religiões de matriz africana o sacrifício ritual de animais representa um símbolo milenar de suas crenças, ou seja, um dogma essencial à prática do culto das suas Divindades" (COELHO; OLIVEIRA; LIMA, 2016, p. 60)

7 Conforme o censo do IBGE, em 2010, havia: a) 588.797 pessoas que disseram ser praticantes de umbanda e candomblé; b) 123.280.172 praticantes da católica apostólica romana; c) e 42.275.440 praticantes de religiões evangélicas (IBGE, 2010). 
A discriminação por motivo de crença, no caso das religiões afro-brasileiras, está indissociavelmente vinculada à discriminação étnica, visto que a percepção generalizada que se tem dessas religiões, obviamente relacionada à sua origem geográfica e à maioria de seus adeptos, é de que se trata de "coisa de preto", de "macumbeiro". Transfere-se e potencializa-se o preconceito contra os negros em geral, que têm a sua prática religiosa associada à ideia de práticas primitivas, arcaicas e de feitiçaria.

A associação é evidente: não gostar dos negros e proscrever o sacrifício ritual de animais, pois esta é uma prática de crenças professadas por aqueles. "Tanto é assim que as justificativas dos projetos de lei que tentam proibir o sacrifício religioso de animais estão recheadas de categorias conceituais que remetem a julgamentos de natureza moral, tais como primitivo/civilidade, atraso/progresso/evolução, mal-estar/constrangimento/ respeito" (COELHO; OLIVEIRA; LIMA, 2006, p. 64).

Analisada sob essa perspectiva, a proibição do sacrifício de animais revela contornos ainda mais agressivos aos direitos fundamentais e à Constituição brasileira, fortemente empenhada em combater o preconceito de raça $\left(\operatorname{art.} 3^{\circ}\right.$, IV) e a prática do racismo (art. $5^{\circ}$, LXII).

A preocupação ambientalista com o bem-estar dos animais, amparada normativamente, partidária de uma concepção moral holística (MACHADO, 2018) e solidarística, acaba por prestar-se a acobertar um sentimento incompatível com o próprio ideário de profundo respeito pela dignidade dos seres vivos (que anima os ecologistas), a revelar o que os seres humanos podem apresentar de mais nefasto: a indiferença, o repúdio, a exclusão por conta da cor da pele. Afinal, o desenvolvimento sustentável não prega que todas as espécies devem poder viver e reproduzir-se em harmonia?

É preciso ficar atento a uma apropriação discursiva desvirtuada da preocupação ambientalista com a crueldade contra os animais, que associa o sacrifício a uma demonstração de atraso e imbecilidade das culturas negras. Na síntese de Teixeira (2015): "Utilizando-se das leis ambientais e de proteção aos animais o discurso da selvageria e da barbárie se agrega ao discurso de práticas anti-higiênicas e poluentes". Esse autor aponta outros pretextos para proscrever práticas das religiões de matriz africana, tais como "supostos problemas de saúde pública e o barulho dos atabaques" (TEIXEIRA, 2015), que se tornam, assim, ensurdecedoras, insuportáveis aos grupos religiosos e culturais hegemônicos.

Nos Estados Unidos, a Corte Suprema entendeu, no julgamento do caso Church of the Lukumi Babalu Aye, Inc. vs. City of Hialeah (1993), que 
a religião afrocaribenha da Santeria, na Flórida, estava tendo sua liberdade religiosa violada. A cidade de Hialeah tinha aprovado um conjunto de normas voltadas a impedir o sacrifício animal, sob a justificativa direta de velar pela saúde, moralidade pública e pela vida dos animais, restringindo o abate somente para finalidades alimentares. Os adeptos da Santeria buscaram no Judiciário a proteção da liberdade religiosa garantida pela Primeira Emenda da Constituição americana e alegaram a inconstitucionalidade das leis. A Corte Suprema dos EUA entendeu que as leis municipais eram hostis à religião Santeria em específico e utilizavam-se da "dissimulação" nas justificativas para proibir apenas o sacrifício de animais daquela prática religiosa. A "proibição seletiva de apenas certos tipos de matança demonstrava um direcionamento inadmissível a uma expressão religiosa" (CASSUTO, 2015, p. 32).

A Corte citou, por exemplo, que, no Regulamento 87-71, havia a exigência de um propósito primário de consumo, isentando a "matança Kosher" e condenando o sacrifício nas religiões de matriz africana que visam, inicialmente, a oferenda aos orixás (PASSALACQUA, 2006). A Corte Suprema declarou também que, "se o objetivo de uma norma é infringir ou restringir condutas por causa de sua motivação religiosa, a lei não é neutra ou de aplicabilidade geral e, portanto, é incompatível com a Cláusula de Livre Exercício" (BRASIL, 2018, p. 13).

O exercício de ponderação entre diretrizes constitucionais parcialmente conflitantes não deve deixar de considerar, por um lado, o peso das normas constitucionais que se voltam claramente contra a discriminação étnica relacionada aos cultos de matriz africana e, por outro lado, que a própria proteção ambiental em que se insere a vedação de crueldade contra animais não pode tolerar a discriminação racial. Verifica-se que um dos pratos da balança tem o peso acrescido, enquanto o peso do outro é diminuído.

\section{PRÁTICAS CULTURAIS E DIVERSIDADE}

Apesar da laicidade do Estado e do pluralismo como característica da sociedade brasileira, que deve nortear a aceitação de uma pluriconfessionalidade (PIRES, 2012), fato é que existe uma estigmatização das crenças afro-brasileiras. Daí que a Constituição de 1988 tenha protegido as manifestações das culturas populares, indígenas e afro-brasileiras, e das de outros grupos participantes do processo civilizatório nacional (art. 215, 
$\S 1^{\circ}$ ), bem como determinado a democratização do acesso aos bens de cultura (art. $\left.215, \S 3^{\circ}, \mathrm{IV}\right)$ e a valorização da diversidade étnica e regional (art. $\left.215, \S 3^{\circ}, \mathrm{V}\right)$.

Almeja-se o reconhecimento recíproco e a participação paritária objetiva e intersubjetiva, como defende Nancy Fraser (2010). A participação paritária intersubjetiva "proíbe padrões culturais que depreciem sistematicamente algumas categorias de pessoas e as qualidades a elas associadas, seja por sobrecarregá-las com uma excessiva 'diferença' dos outros, seja por falhar em reconhecer sua distintividade" (FRASER, 2010, p. 181).

A análise de eventual conflito entre a liberdade religiosa e a prática de crueldade em face dos animais não pode fundar-se em uma ordem de valores culturais que atribua às religiões afro-brasileiras um lugar desprezível e às religiões cristãs eurocêntricas o estatuto de adequação e correção. Resulta o descabimento de uma intervenção estatal de restrição a determinada religião; o Estado pode intervir apenas para salvaguardar todas elas, porque "[a] perspectiva democrática do pluralismo pode demandar uma intervenção estatal justamente para propiciar condições de igualdade, quando o Poder Público deve sim interferir, mas justamente para assegurar a competição religiosa" (ROTHENBURG, 2014b, p. 44). Na expressão de Luís Roberto Barroso (2012), "significa que o Estado não deve escolher lados quando diferentes concepções razoáveis de vida boa estão em conflito".

Em razão desse cenário, os adeptos das religiões de matriz africana ressaltam que: a) o sacrifício ou sacralização é respeitoso, realizado apenas por pessoa escolhida e preparada pela divindade adorada para executar tal tarefa; b) existe um cuidado especial para com os animais que serão sacralizados, pois o sacrifício deve ser realizado sem oferecer sofrimento para o animal, pois ele é considerado sagrado e não deve padecer crueldade e negatividade; c) a consagração atinge, para além do objeto sacralizada, tanto a pessoa que se encarrega da cerimônia (o sacrificador), quanto o sacrificante (fiel que fornece a vítima do sacrifício), que pode ser um indivíduo ou uma coletividade (COELHO; OLIVEIRA; LIMA, 2016; ORO; CARVALHO; SCURO, 2017).

Assim, a diretriz constitucional de respeito e valorização da diversidade cultural milita em favor do sacrifício ritual de animais por religiões afrobrasileiras, pois o caráter pluriétnico e multicultural da sociedade brasileira está constitucionalizado. É preciso, assim, tanto proteger as formas culturais não hegemônicas, quanto promover a convivência entre as diversas manifestações culturais. Esse "polifacetismo cultural" deve desenvolver 
seus diversos âmbitos "simultaneamente de forma paralela, tanto com intercâmbios dos elementos próprios de cada forma, como competindo inclusive uma cultura com outra", observa Peter Häberle (2000, p. 31).

Na Alemanha, em 2002, o Tribunal Constitucional Federal afirmou que um açougueiro muçulmano podia abater animais de modo ritual, pois às normas que asseguravam a prática profissional poderiam ser acrescidas as inerentes à liberdade religiosa. $\mathrm{O}$ açougueiro fora acusado de infringir dispositivos da Lei Alemã para Proteção dos Animais, visto que, em sua atividade profissional, seguia os preceitos religiosos islâmicos que determinam o sacrifício dos animais sem prévia insensibilização. "Segundo a referida Corte, a degola sem prévio aturdimento consistia em 'uma atitude fundamentalmente religiosa', que inclui os crentes sunitas muçulmanos e os obriga a sacrificar os animais como ordenam as regras da sua religião" (COELHO; OLIVEIRA; LIMA, 2016, p. 65-66).

O Tribunal Europeu de Direitos Humanos, ao julgar, em 27/06/2000, o caso Cha'are Shalom Ve Tsedek v. France, fixou que o direito de manifestação religiosa, previsto no artigo $9^{\circ}$ da Convenção Europeia dos Direitos Humanos, protege a prática do abate religioso. Porém, indeferiu o pedido apresentado pela associação litúrgica judaica Cha'are Shalom Ve Tsedek para obter a certificação necessária para praticar o ritual de abate de acordo com as rigorosas prescrições exigidas por sua religião, sob a justificativa de que " $[0]$ direito de manifestação religiosa não implica a garantia de participar pessoalmente da execução do abate ou do processo de certificação subsequente [...] desde que os adeptos dessa religião não sejam impedidos de obter carne de outra forma, em conformidade com padrões de suas crenças" (BRASIL, 2018, p. 4-6).

Não se ignora que também a preocupação ambientalista representa um dado cultural relevante do constitucionalismo contemporâneo, ou seja, a dimensão ecológica faz parte da ideia de Constituição. Assim, a proibição de submissão dos animais à crueldade atende a uma expectativa cultural e compõe a moralidade pública. Nessa medida, diminui o peso favorável do argumento cultural às práticas rituais de religiões afro-brasileiras, que ficam parcialmente neutralizadas em seu próprio âmbito (cultura $\times$ cultura). Porém, enquanto a preocupação ambientalista é geral e corresponde a um padrão cultural amplo, o abate ritual de animais é uma manifestação de cultura não hegemônica, a merecer especial atenção. Ademais, é preciso verificar em que medida essa prática cultural de sacrifício ritual de animais não implica crueldade. 


\section{DIREITO À ALIMENTAÇÃO?}

O consumo dos animais abatidos ritualisticamente impõe ainda a consideração do direito fundamental social à alimentação, expressamente previsto no art. $6^{\circ}$ da Constituição brasileira, e pode representar um peso adicional em favor dessa prática religiosa.

Não se trata apenas da alimentação do corpo, nem só da alimentação humana, visto que há, ainda, "a necessidade de sustento das próprias divindades que dependeriam dessas práticas para se manterem poderosas e benevolentes" (TEIXEIRA, 2015). Isso evoca a dimensão cultural presente no consumo dos animais sacrificados e que é reconhecida a determinadas tradições. O consumo dos animais abatidos ocorre, então, por razões religiosas e culturais que incorporam a prática do compartilhamento do alimento entre a comunidade e seus ancestrais.

Para as religiões de matriz africana, a comida é entendida como alimento do corpo e também do espírito. Portanto, "o consumo da carne de um animal que foi oferecido é visto como uma forma de comunhão com os deuses", esclarecem Coelho, Oliveira e Lima (2016, p. 61), sendo que não são todas as partes do animal que são ofertadas às divindades, mas somente moela, fígado, coração, pés, asas, cabeça e o sangue. Assim, a maior parte da carne é consumida pelos fiéis e visitantes, não havendo desperdício. "A transformação do animal sacrificado em alimento representa, portanto, uma dinâmica de solidariedade entre os envolvidos no ritual e todos podem usufruir do alimento".

A ideia de consumo alimentar expressa-se em dois planos, porque "as divindades comem, elas precisam ser alimentadas. [...] quando uma entidade espiritual não é alimentada ela morre, ela deixa de existir" (VIDA, 2007 , p. 298). Há o consumo pelas entidades espirituais e por todos aqueles, iniciados e não iniciados, que estejam presentes e queiram se alimentar do banquete que celebra a vida (VIDA, 2007).

Mesmo que não ocorra o consumo pelos fiéis, não resta diminuída a importância ritual do abate, que se justifica inteiramente como expressão da liberdade religiosa. Nesse sentido, parece reducionista o condicionamento feito pelo Min. Marco Aurélio, relator do RE 494.601 (BRASIL, 2018), da constitucionalidade do sacrifício de animais em ritos religiosos de qualquer natureza ao consumo humano da carne. A exigência de que o abate ritual esteja vinculado ao consumo da carne parece deixar em segundo plano a ideia do sagrado e da importância da imolação para a ligação 
dos adeptos dessas religiões com os deuses que veneram. Ademais, soa como uma aproximação com as práticas judaicas (abate Kosher) e islâmicas (abate Halal), que exigem obediência a métodos de abate de animais determinados por preceitos religiosos, para o consumo de carne.

\section{OS DIREITOS DOS ANIMAIS E A PROIBIÇÃO À CRUELDADE}

Os direitos dos animais encontram guarida na Constituição brasileira não apenas por meio da vedação expressa à crueldade, mas também por força do preceito afirmativo de proteção à fauna, constante do mesmo inciso VII do $\S 1^{\circ}$ do art. 225. De modo mais amplo, ainda que implícito, a Constituição parece consagrar a dignidade dos demais seres vivos, visto que adjetiva a dignidade "da pessoa humana" no art. $1^{\circ}$, III (como fundamento de nossa república), a sugerir que ela não é atributo exclusivo (ROTHENBURG, 2014a).

Neste novo contexto, que foge às limitações impostas por uma moldura exclusivamente antropocêntrica, encontra-se a concepção de dignidade pautada na senciência, ou seja, na característica que os animais têm de "pensamento, percepção de si e do mundo a sua volta; apresentando sentidos sensoriais, $[\ldots]$ assim como inteligência prática (autonomia prática) e outras qualidades psíquicas que permitem uma relação efetiva com o mundo exterior [...]" (VIOTTO, 2016, p. 45-46). Há, portanto, uma atribuição de "valor por si" à natureza e ao meio ambiente (BARRETO; MACHADO, 2016).

Afinal, como pontua Judith Butler (2018, p. 120), “estamos, ainda que sejamos distintos, ligados um ao outro e a processos vivos que vão além da forma humana". De fato, "o aprofundamento da consciência ecológica e a evolução do direito possibilitaram conceituar os animais como seres 'sensíveis", o que lhes confere um "interesse incontestável de não sofrer", assevera Paulo Affonso Leme Machado (2018, p. 176).

O Supremo Tribunal Federal tem afirmado a proibição de submeter animais à crueldade em casos de práticas culturais populares, resolvendo o conflito de bens constitucionais em favor do ambiente ecologicamente equilibrado. Foram pelo menos três ocasiões em que houve tal afirmação: a) recurso extraordinário 153.531-8/SC, relator Min. Marco Aurélio, julgado em 3 de junho de 1997. Nele se discutia a farra do boi, tradicional festejo de origem açoriana, semelhante a uma "corrida" de touros, realizado em Santa Catarina;

b) ações diretas de inconstitucionalidade $1.856 / \mathrm{RJ}$ e $2.514-7 / \mathrm{SC}$, em face, 
respectivamente, de leis dos Estados do Rio de Janeiro e de Santa Catarina que autorizavam a rinha (briga) de galos;

c) ação direta de inconstitucionalidade 4.983/CE em face de lei do Estado do Ceará que autorizava a vaquejada, tradicional festejo semelhante a um rodeio.

O último caso, da vaquejada, revelou o peso da tradição cultural nordestina e implicou um embate institucional entre o Poder Judiciário e o Parlamento, sendo que o Congresso Nacional, para reverter a decisão do Supremo Tribunal Federal, aprovou a Emenda Constitucional 96/2017 que, com o objetivo de conferir "interpretação autêntica" ao art. $225, \S 1^{\circ}$, VII (na verdade, houve uma limitação expressa ao âmbito de aplicação desse dispositivo), acrescentou um $\S 7^{\circ}$ àquele artigo para não se considerarem cruéis as práticas desportivas que utilizem animais, desde que sejam manifestações culturais, conforme o $\S 1^{\circ}$ do art. 215 da Constituição Federal, e que sejam registradas como bem de natureza imaterial integrante do patrimônio cultural brasileiro, devendo ser regulamentadas por lei específica que assegure o bem-estar dos animais envolvidos.

Mas, na arguta crítica de Machado (2018, p. 177): “A crueldade não se transforma em benignidade só por efeito de uma lei, ainda que constitucional, pois uma lei não tem força para transmudar 'água em vinho', rompendo a ordem natural das coisas". Temos nesse exemplo, ao invés de um diálogo constitucional, “uma 'guerra de gritos', em que o Parlamento busca simplesmente substituir a interpretação constitucional judicial pela parlamentar" (BRANDÃO, 2012, p. 304).

Em nenhum desses casos houve conflito com a liberdade religiosa, embora a ponderação opusesse outros fenômenos culturais tradicionais, porém de natureza lúdica. É provável que a importância social da religião seja maior do que a desses eventos em que animais são submetidos a crueldade, o que militaria em prol da vedação.

Todavia, a proibição de submissão dos animais a crueldade é um valor constitucional consagrado em regra constitucional expressa e aproxima-se de um direito fundamental, relacionado a uma dignidade inerente aos seres vivos em geral. No sopesamento com outros bens constitucionais, inclusive a liberdade religiosa e a igualdade (não discriminação), será preciso levar na devida consideração tal vedação. As situações concretas é que indicarão a presença e intensidade da crueldade, que poderá, sim, levar à restrição de outras normas da Constituição eventualmente conflitantes. Um argumento exagerado invocaria que não se pode admitir o sacrifício ritual 
humano em nome da liberdade religiosa. É certo que práticas que inflijam sofrimento sério e imoderado a animais não devem ser admitidas, com a prevalência da perspectiva ecológica.

Ocorre que o sacrifício ritual de animais, ao menos no que se refere àquele realizado pelos judeus (abate Kosher), pelos muçulmanos (abate Halal) e pelos adeptos de religiões afro-brasileiras, caracteriza-se por uma preocupação em evitar o sofrimento dos animais, o que coloca em cheque a própria existência de crueldade. Para as religiões de matriz africana, é preciso que o animal seja oferecido às divindades (orixás) na melhor condição possível, havendo uma razão dogmática para que se evite o sofrimento e a dor. Tal como no judaísmo e no islã, a pessoa encarregada do abate tem uma importante função litúrgica e recebe um treinamento cuidadoso, desenvolvendo expertise justamente para evitar a crueldade: “[e]ssas práticas são realizadas por um iniciado preparado ritualisticamente para tal finalidade, o axogum", esclarece Teixeira (2015). Tal preocupação reforça - ao invés de negar - a interdição constitucional. É quase um sacrilégio (ou uma ironia) acusar a prática de cruel. Para efeitos de ponderação normativa, o próprio argumento da crueldade é neutralizado ou sensivelmente minorado, ou seja, o peso da "acusação" de crueldade é minimizado.

Refutando, também, a ligação entre o sacrifício de animais e a prática de crueldade, Samuel Santana Vida (2007, p. 297) afirma que "não há qualquer lugar do ponto de vista teológico, do ponto de vista ritualístico, nas religiões de matrizes africanas para o sofrimento dos animais, o sofrimento pelo sofrimento". Explica o autor, ainda, que não há, na tradição religiosa de matriz africana, a dimensão de "expiar os pecados", como acontece na tradição cristã, e tampouco de "substituir o pecador, imolando o animal em seu nome", como ocorre na tradição judaica. Fábio Carvalho Leite (2013, p. 174) pontua que "o sofrimento do animal objeto do sacrifício é o mesmo do animal abatido para consumo, não podendo ser este um argumento válido para um questionamento jurídico do rito religioso, salvo, é claro, se for demonstrado um tratamento cruel e de tortura maior no primeiro caso do que no segundo".

Vê-se, assim, que o exercício de ponderação aqui proposto, oferecido pelo abate ritual de animais por religiões afro-brasileiras, em nenhum momento descuida do importante mandamento constitucional que proíbe submeter os animais a crueldade. 


\section{PONDERAÇÃO: ATÉ ONDE PODE IR A LIBERDADE RELIGIOSA}

A complexidade das sociedades contemporâneas e o forte acento pluriétnico da população brasileira geram possibilidades concretas de conflito entre bens constitucionalmente protegidos, muitos deles formulados como direitos fundamentais. É preciso, assim, partir da premissa - radicalmente democrática - de que não existem direitos fundamentais absolutos, que estejam imunizados da influência dos demais direitos fundamentais (e de outros bens constitucionalmente protegidos). Nessa esteira, Alexandre de Moraes (2016, p. 50) expõe que: "Obviamente, assim como as demais liberdades públicas, também a liberdade religiosa não atinge grau absoluto, não sendo, pois, permitidos a qualquer religião ou culto atos atentatórios à dignidade da pessoa humana, sob pena de responsabilização civil e criminal".

A Constituição da República assegura com ênfase a liberdade religiosa, num contexto multicultural e de laicidade estatal, mas também dispõe expressamente, no âmbito da proteção ecológica, que é vedada a crueldade contra os animais (art. 225, § $1^{\circ}$, VII). Não há como, portanto, deixar de levar em consideração esse dispositivo constitucional ao efetuar o balanceamento diante do presente conflito normativo, que envolve o sacrifício ritualístico de animais. Atos que submetam os animais a graus intensos e injustificados de sofrimento, caracterizando crueldade, ultrapassam o limite constitucional do exercício de direitos e fundamentam uma intervenção estatal.

Todavia, as práticas religiosas em questão, componentes da liturgia das religiões afro-brasileiras, à semelhança das práticas de outras religiões como o judaísmo (abate Kosher ou Kasher) e o islamismo (abate Halal), têm uma preocupação particular em evitar o sofrimento dos animais. Há pessoas especialmente encarregadas do sacrifício e métodos para que a morte se dê de modo aceitável. Verifica-se, assim, nas religiões de matriz africana, o menor atingimento razoável ao bem constitucional em conflito, uma das exigências da aplicação rigorosa do critério da proporcionalidade. Outro limite, por exemplo, seria o risco de extinção dos animais sacrificados. Mas, conforme explicado por Flávio Carvalho Leite (2016, p. 173), os estudos constatam que "os sacrifícios realizados nos cultos de religiões de matriz africana não envolvem espécies em extinção nem aquelas que gozam de proteção especial por parte do Poder Público - hipóteses que 
tornariam ilegítimas as práticas, ainda que religiosamente motivadas".

O sacrifício de animais constitui um aspecto essencial das religiões afro-brasileiras, que, tal como em relação às comunidades de fé em geral, compõem-se de um todo incindível de convicções (crenças) e práticas (condutas), sendo que estas são manifestações concretizadoras daquelas. Destaca Jayme Weingartner Neto (2018, p. 272) que "a conduta em apreço assume relevância estrutural para tais confissões, pelo que sua supressão significaria erosão do conteúdo essencial da religião professada, com reflexos no conteúdo em dignidade humana". Proibir o sacrifício ritualístico de animais significa, na prática, inviabilizar a própria prática dos cultos afro-brasileiros e, assim, proscrever tais religiões. O grau de afetação do direito de religião, no caso concreto, afigura-se insuportável, o que deve ser evitado no manejo do critério da proporcionalidade.

A propósito, as considerações de Jónatas Machado (1996, p. 223) calham perfeitamente: "a liberdade religiosa deve proteger a conduta religiosa, a liberdade de actuação e autoconformação de acordo com as próprias convicções, numa medida tão ampla quanto o permita uma ponderação de bens constitucionalmente saudável".

Nas vezes em que o Supremo Tribunal Federal afirmou a proibição de crueldade contra os animais (farra do boi ${ }^{8}$, rinha de galos ${ }^{9}$ e vaquejada ${ }^{10}$ ), não estava em jogo a liberdade religiosa, que se configura, no presente caso, como um ponderável direito fundamental a ser levado em consideração. Com efeito e com o devido respeito aos demais direitos e bens envolvidos, não se pode comparar o sacrifício ritualístico de animais, como prática essencial das religiões afro-brasileiras, com festas e manifestações populares tradicionais ou jogos de apostas. Além disso, enquanto o sacrifício de animais em cultos e liturgias das religiões de matriz africana é feito com uma preocupação especial em evitar a crueldade, a farra do boi, a rinha de galos e a vaquejada provocam intenso sofrimento aos animais.

A Lei n. 11.915/2003 do Estado do Rio Grande do Sul (com as alterações da Lei n. 12.131/2004) tem uma dupla e contraditória influência religiosa. Ao estabelecer amplamente a vedação ao sofrimento e sacrifício de animais, ela vai ao encontro da percepção de determinadas e influentes

8 Recurso Extraordinário 153.531/SC, relator para o acórdão Min. Marco Aurélio, julgamento em 3 de junho de 1997.

9 Ação Direta de Inconstitucionalidade 1.856/RJ, relator Min. Celso de Mello, julgamento em 26/05/2011.

10 Ação Direta de Inconstitucionalidade 4.983/CE, relator Min. Marco Aurélio, julgamento em 6 de outubro de 2016. O Congresso Nacional viria a superar esse entendimento ao aprovar a Emenda Constitucional 96/2017, que acrescenta o $\S 7^{\circ}$ ao art. 225 da Constituição. 
religiões que rejeitam dogmaticamente os rituais afro-brasileiros. E, ao estabelecer a permissão excepcional de "livre exercício dos cultos e liturgias das religiões de matriz africana", a alteração legislativa passa a contemplar estas concepções (historicamente discriminadas). Percebe-se que, ao inclinar-se para as religiões predominantes - tal como a lei do Município de Cotia (SP), acima referida -, a legislação gaúcha, em sua versão original, sufocava a prática das religiões afro-brasileiras ("minoritárias"), enquanto, ao excepcionar os cultos e liturgias destas, a norma não interfere nas práticas daquelas religiões predominantes.

$\mathrm{O}$ que contraria o direito fundamental de liberdade religiosa, no caso - bem como os princípios da isonomia e da laicidade estatal, assim como o direito de manifestação cultural -, é a restrição representada pela vedação generalizada ao sacrifício de animais. Jónatas Machado (1996, p. 231) tem uma lição precisa a respeito desse problema de restrição a direitos fundamentais: "A invocação do direito à liberdade religiosa só se justificaria nos casos em que se suspeitasse do carácter religioso dos fundamentos da restrição, nomeadamente, quando esta fosse para além do que seria de razoável esperar à luz de uma ponderação daqueles direitos com outros bens constitucionalmente protegidos".

É plausível que não haja crueldade contra os animais na prática do sacrifício ritualístico nos "cultos e liturgias das religiões de matriz africana". Admitamos, contudo e para argumentar, que se produza um impacto no âmbito de proteção do art. $225, \S 1^{\circ}$, VII, da Constituição. Analisada, então, a proporcionalidade dessa limitação ao espectro de incidência da norma, a aplicação analítica do critério demonstra que se cumprem seus diversos aspectos ou requisitos. A permissão a que as religiões afro-brasileiras realizem o sacrifício ritualístico de animais, considerada como uma restrição à determinação constitucional de que os animais não sofram crueldade, da forma tradicional como é realizado o sacrifício, é uma medida adequada, pois tem o condão de assegurar a prática religiosa; é uma media necessária, pois não existe outro meio (e deveria ser tão apropriado quanto) que viabilize a prática religiosa; é uma medida proporcional em sentido estrito, pois a sensibilidade dos animais é razoavelmente preservada, em comparação com a inviabilidade total que a proibição do sacrifício de animais significa para o exercício das religiões afro-brasileiras.

Portanto, somente se demonstrada, de forma inequívoca, uma prática que configure crueldade, é que caberá ao Estado intervir na liberdade religiosa para conter o sacrifício ritualístico. 
Por outro lado, permitir a edição de leis que proíbam mais ou menos incondicionalmente o sacrifício de animais, como feito pelo Município de Cotia (SP), é respaldar que o Estado se utilize de uma de suas mais incisivas manifestações de poder, que é o legiferante, para atingir direta e desproporcionalmente as religiões afro-brasileiras, para as quais o abate ritual é indispensável, vinculado à tradição e à ancestralidade. Sob a aparência de uma legislação geral, o Estado acaba por constranger e penalizar determinadas crenças utilizando-se de um discurso jurídico-constitucional para operacionalizar antigas formas de coerção e discriminação religiosa em face das religiões minoritárias que concorrem com as religiões predominantes no Brasil (cristãs).

Não admira, portanto, que, sintomaticamente, a aplicação de leis proibitivas parece não ser reivindicada em outras situações de sacrifício de animais segundo preceitos religiosos, que não dizem respeito às religiões de matriz africana. É o que ocorre com o comércio de carne animal para mercados judeus e muçulmanos, segundo Teixeira (2015): "As agroindústrias brasileiras com foco no mercado consumidor estrangeiro estão se especializando em realizar o abate religioso, para conquistar povos nos quais a fé rege também os hábitos alimentares". Percebe-se o quão discriminatória é a edição e a aplicação (seletiva) de leis que vedam o sacrifício ritual de animais no Brasil. Então, "se o abate em frigoríficos difere do realizado nos terreiros é simplesmente por ser quantitativamente maior e qualitativamente menos respeitoso" (ORO; CARVALHO; SCURO, 2017, p. 247).

É constitucionalmente legítimo permitir a sacralização de animais para fins religiosos, na medida em que se admitem os modos sacrificiais de matar animais para fins alimentares (abate Halal e Kosher), os métodos não sacrificiais de matar animais para fins alimentares em geral e, em certos casos, para pesquisas médicas e de cosméticos, bem como a utilização de animais com finalidade de entretenimento e para trabalho. Em nenhuma dessas situações, no entanto, está autorizada a submissão dos animais à crueldade e existe um dever estatal de proteção dos animais contra tratamento cruel.

\section{CONSIDERAÇÕES FINAIS}

A análise, pelo Supremo Tribunal Federal brasileiro, da inconstitucionalidade da legislação que proíbe o sacrifício ritualístico de animais revelou uma adequada ponderação de bens constitucionalmente tutelados.

Pesa a favor da permissão o direito de crença e manifestação religiosa, 
previsto no art. $5^{\circ}$, VI, da Constituição brasileira, pois a proibição do sacrifício ritualístico de animais inviabiliza o exercício das religiões de matriz africana.

Pesa também a favor da permissão a igualdade com que devem ser tratadas todas as pessoas, sem discriminação de natureza religiosa (art. $5^{\circ}$ da Constituição). A proibição generalizada do sacrifício de animais atinge direta e desproporcionalmente os adeptos das religiões afro-brasileiras, em especial os afrodescendentes, provocando uma odiosa discriminação.

Pesa a favor da permissão o princípio da laicidade do Estado brasileiro (Constituição, art. 19, I), que deve conferir especial proteção às religiões historicamente marginalizadas. Com efeito, a proibição legal do sacrifício ritualístico de animais dispõe os aparelhos de repressão estatal contra as religiões afro-brasileiras, enfraquecendo-as indevidamente em face de outras religiões mais poderosas.

Pesa ainda a favor da permissão o direito fundamental de identidade cultural, pois a crença e a prática religiosas são manifestações culturais constitutivas da identidade das pessoas e grupos. As religiões de matriz africana são expressões essenciais da identidade cultural de significativo contingente da população brasileira, incumbindo ao Estado a proteção das manifestações das culturas afro-brasileiras, nos expressos termos do art. $215, \S 1^{\circ}$, da Constituição, com vistas à instituição de um ambiente de convivência entre as diversas expressões religiosas. Nesse contexto, a rica experiência cultural captada pela legislação do Rio Grande do Sul (e cuja validade foi afirmada pelo Supremo Tribunal Federal), ao permitir o "livre exercício dos cultos e liturgias das religiões de matriz africana”, deve ser valorizada no contexto da federação brasileira.

A favor da permissão pesa, ademais, a inexistência de crueldade no sacrifício ritualístico de animais em religiões de matriz africana, dado o cuidado em não ocasionar sofrimento aos animais como objetivo da sacralização. Nessa medida, o sacrifício de animais deve ser considerado um comportamento religioso protegido e tanto as leis, como as decisões administrativas e judiciais que afetem o exercício da liberdade religiosa constituem restrições indevidas.

A ponderação realizada pelo Supremo Tribunal Federal no julgamento do Recurso Extraordinário (RE) 494.601/RS, ao concluir pela validade constitucional do sacrifício ritualístico de animais, mostrou-se acertada e não desconsidera a proibição de submeter os animais a práticas que os submetam a crueldade. 


\section{REFERÊNCIAS}

ASSEMBLEIA GERAL DAS NAÇÕES UNIDAS. Declaração sobre a eliminação de todas as formas de intolerância e discriminação fundadas na religião ou nas convicções, 25 de novembro de 1981 (Resolução 36/55). Disponível em: http:/www2.camara.leg.br/atividade-legislativa/comissoes/comissoes-permanentes/cdhm/comite-brasileiro-de-direitos-humanos-e-politica-externa/DecElimFormIntDisc.html. Acesso em: 20 set. 2018.

BARRETO, L. M.; MACHADO, P. A. L. A construção do diálogo e da solidariedade e a proteção do bem ambiental e da natureza na concepção universal do humano a partir de uma leitura da Encíclica Laudato Si. Veredas do Direito, Belo Horizonte, v. 13, n. 26, p. 319-336, maio/ago. 2016. Disponível em: http://www.domhelder.edu.br/revista/ index.php/veredas/ article/view/720. Acesso em: 10 out. 2018.

BARROSO, L. R. Aqui, lá e em todo lugar: a dignidade humana no direito contemporâneo e no discurso transnacional. Revista dos Tribunais, São Paulo, ano 101, v. 919, p. 127-196, maio 2012. Disponível em: http:// www.luisrobertobarroso.com.br/wp-content/uploads/2017/09/aqui_em_ todo_lugar_dignidade_humana_direito_contemporaneo_discurso_transnacional.pdf. Acesso em: 25 mar. 2020.

BIELEFELDT, H. Interim report of the Special Rapporteur on freedom of religion or belief, Genève: OHCHR, 2016. Disponível em: https://www. ohchr.org/Documents/Issues/Religion/A-71-269_en.pdf. Acesso em: 20 set. 2018.

BRANDÃO, R. Supremacia judicial versus diálogos constitucionais: a quem cabe a última palavra sobre o sentido da constituição? Rio de Janeiro: Lumen Juris, 2012.

BRASIL. Presidência da República. Lei n. 13.105, de 16 de março de 2015. Código de Processo Civil. Disponível em: http://www.planalto.gov.br/ccivil_03/_Ato2015-2018/2015/Lei/L13105.htm. Acesso em: 26 mar. 2020.

BRASIL. Presidência da República. Lei n. 12.288, de 20 de julho de 2010. Institui o Estatuto da Igualdade Racial; altera as Leis $\mathrm{n} \underline{\mathrm{os}} 7.716$, de 5 de janeiro de 1989, 9.029, de 13 de abril de 1995, 7.347, de 24 de julho de 1985, e 10.778, de 24 de novembro de 2003. Disponível em: http://www. 
planalto.gov.br/ccivil_03/_Ato2007-2010/2010/Lei/L12288.htm. Acesso em: 26 mar. 2020.

BRASIL. Presidência da República. Constituição da República Federativa do Brasil de 1988. Disponível em: http://www.planalto.gov.br/ccivil_03/ constituicao/constituicao.htm. Acesso em: 26 mar. 2020.

BRASIL. Tribunal de Justiça do Estado do Rio Grande do Sul. Ação direta de inconstitucionalidade n. 70010129690 (TJE). Acórdão. 2005. Disponível em: https://sistemas.stf.jus.br/peticionamento/api/peca/recuperarpdf/311160331. Acesso em: 10 out. 2018.

BRASIL. Procurador Geral da República. Parecer n. 905 no Recurso Extraordinário 494.601/RS, 2007, p. 668-690. Disponível em: https:// sistemas.stf.jus.br/peticionamento/api/peca/recuperarpdf/311160331. Acesso em: 11 out. 2018.

BRASIL. Tribunal de Justiça do Estado de São Paulo. Ação direta de inconstitucionalidade n. 2232470-13.2016.8.26.0000. Acórdão. 2017. Disponível em: https://esaj.tjsp.jus.br/cjsg/getArquivo.do?conversationI$\mathrm{d}=\& \mathrm{cdAcordao}=10457246 \& \mathrm{cdForo}=0 \&$ uuidCaptcha=sajcaptcha_ff71da$7 \mathrm{f} 4505423 \mathrm{fa} 318 \mathrm{~d} 8 \mathrm{ae} 3448 \mathrm{bb} 13 \& \mathrm{v} 1 \mathrm{Captcha}=$ eqiAi\&novoV1Captcha $=$. Acesso em: 18 set. 2018.

BRASIL. Supremo Tribunal Federal. Ação direta de inconstitucionalidade n. 4.983/CE. Disponível em: http://redir.stf.jus.br/paginadorpub/paginador.jsp?docTP=TP\&docID=12798874. Acesso em: 26 mar. 2020.

BRASIL. Supremo Tribunal Federal. Ação direta de inconstitucionalidade n. 4.439. Íntegra do voto do ministro Ricardo Lewandowski. Disponível em: http://www.stf.jus.br/arquivo/cms/noticiaNoticiaStf/anexo/ ADI4439mRL.pdf. Acesso em: 18 set. 2018.

BRASIL. Supremo Tribunal Federal. Ação direta de inconstitucionalidade n. 2.514-7/SC. Disponível em: http://redir.stf.jus.br/paginadorpub/paginador.jsp?docTP=AC\&docID=266833. Acesso em: 26 mar. 2020.

BRASIL. Supremo Tribunal Federal. Ação direta de inconstitucionalidade n. 1.856/RJ. Disponível em: http://redir.stf.jus.br/paginadorpub/paginador. jsp?docTP=AC\&docID=628634. Acesso em: 26 mar. 2020.

BRASIL. Supremo Tribunal Federal. Boletim de jurisprudência internacional: sacrifício de animais em rituais religiosos, 2018. Disponível em: 
http://sistemas.stf.jus.br/xmlui/handle/123456789/1110. Acesso em: 10 out. 2018.

BRASIL. Supremo Tribunal Federal. Recurso Extraordinário n. 1.096.915$S P$. Disponível em: http://portal.stf.jus.br/processos/detalhe.asp?incidente $=5320716$. Acesso em: 12 ago. 2019.

BRASIL. Supremo Tribunal Federal. Recurso Extraordinário n. 494.601$R S$. Certidão de julgamento e fixação de tese, 2019. Disponível em: https:// sistemas.stf.jus.br/peticionamento/api/peca/recuperarpdf/15339827887. Acesso em: 12 ago.2019.

BRASIL. Supremo Tribunal Federal. Recurso Extraordinário n. 494.601$R S$. Íntegra do voto do ministro relator Marco Aurélio. Disponível em: http://www.stf.jus.br/arquivo/cms/noticiaNoticiaStf/anexo/RE494601MMA.pdf. Acesso em: 20 set. 2018.

BRASIL. Supremo Tribunal Federal. Recurso Extraordinário 153.531-8/ $S C$. Disponível em: http://redir.stf.jus.br/paginadorpub/paginador.jsp?doc$\mathrm{TP}=\mathrm{AC} \&$ docID=211500. Acesso em: 26 mar. 2020.

BREGA FILHO, V.; ALVES, F. B. Da liberdade religiosa como direito fundamental: limites, proteção e efetividade. Revista do Programa de Mestrado em Ciência Jurídica da Fundinopi, n. 11, p. 75-94, 2009. Disponível em: http://seer.uenp.edu.br/index.php/argumenta/article/view/144/144. Acesso em: 20 set. 2018.

BUTLER, J. Corpos em aliança e a politica das ruas: notas para uma teoria performativa de assembleia. Rio de Janeiro: Civilização Brasileira, 2018.

CASSUTO, D. N. Sacrifício de animais e a primeira emenda: o caso da Igreja Lukumi Babalu Aye. Revista Brasileira de Direito Animal (RBDA), Salvador, v. 10, n. 19, p. 15-64, 2015. Disponível em: https://portalseer. ufba.br/index.php/RBDA/article/view/14376/9894. Acesso em: 10 out. 2018 .

COELHO, C. J. H.; OLIVEIRA, L. P. S.; LIMA, K. J. M. Sacrifício ritual de animais não humanos nas liturgias religiosas de matriz africana: "medo do feitiço" e intolerância religiosa na pauta legislativa. Revista Brasileira de Direito Animal (RBDA), Salvador, v. 11, n. 22, p. 53-82, maio/ago. 2016. Disponível em: $<$ https://portalseer.ufba.br/index.php/RBDA/article/ view/17665/11524. Acesso em: 25 set. 2018. 
COTIA. Lei $n$. 1.960, de 21 de setembro de 2016. Dispõe sobre a proibição da utilização, mutilação e/ou o sacrifício de animais em pesquisas, em rituais religiosos ou de qualquer natureza no Município de Cotia, e dá outras providências. Brasil: Liz Serviços Online, 2016. Disponível em: https://leismunicipais.com.br/a/sp/c/cotia/lei-ordinaria/2016/196/1960/ lei-ordinaria-n-1960-2016-dispoe-sobre-a-proibicao-da-utilizacao-mutilacao-e-ou-o-sacrificio-de-animais-em-pesquisas-em-rituais-religiosos-ou-de-qualquer-natureza-no-municipio-de-cotia-e-da-outras-providencias?$\mathrm{q}=$ religiosos. Acesso em: 26 mar. 2020.

FRASER, N. Redistribuição, reconhecimento e participação: por uma concepção integrada da justiça. In: SARMENTO, D.; IKAWA, D.; PIOVESAN, F. Igualdade, diferença e direitos humanos. Rio de Janeiro: Lumen Juris, 2010. p. 167-190.

HÄBERLE, P. Teoría de la Constitución como ciencia de la cultura. Madrid: Tecnos, 2000.

IBGE - INSTITUTO BRASILEIRO DE GEOGRAFIA E ESTATÍSTICA. Censo demográfico: características gerais da população, religião e pessoas com deficiência. Rio de Janeiro: IBGE, 2010. Disponível em: https://www. ibge.gov.br/estatisticas-novoportal/sociais/populacao/9662-censo-demografico-2010.html?edicao $=9749 \& \mathrm{t}=$ destaques. Acesso em: 17 set. 2018 .

LEITE, F. C. A liberdade de crença e o sacrifício de animais em cultos religiosos. Veredas do Direito, Belo Horizonte, v. 10, n. 20, p. 163-177, jul./dez. 2013. Disponível em: http://www.domhelder.edu.br/revista/index. php/veredas/article/view/370/370. Acesso em: 10 out. 2018.

MACHADO, J. E. M. Liberdade religiosa numa comunidade constitucional inclusiva: dos direitos da verdade aos direitos dos cidadãos. Coimbra: Coimbra, 1996.

MACHADO, P. A. L. Direito Ambiental brasileiro. 26. ed. São Paulo: Malheiros, 2018.

MARTINS, L. Tribunal Constitucional Federal Alemão: decisões anotadas sobre direitos fundamentais. Volume 2: Liberdade de consciência e de crença, liberdades de expressão e de comunicação social, liberdades artística e científica. São Paulo: Konrad Adenauer Stiftung - KAS, 2018.

MARTINS, L. Introdução à jurisprudência do Tribunal Constitucional 
Federal Alemão: cinquenta anos de jurisprudência do Tribunal Constitucional Federal Alemão. Montevideo: Fundación Konrad Adenauer, 2005.

MOTA, E. G. Diálogos sobre religiões de matrizes africanas: racismo religioso e história. Revista Calundu, Brasília, DF, v. 2, n. 1, p. 23-48, jan./jun. 2018. Disponível em: http://periodicos.unb.br/ojs311/index.php/revistacalundu/article/view/9543/8434. Acesso em: 9 out. 2018.

MORAES, A. Direito constitucional. 32. ed. São Paulo: Atlas, 2016.

MOREIRA, V. A liberdade de pensamento, de consciência e de religião: uma perspectiva europeia. In: ANJOS FILHO, R. N. (Org.). Direitos humanos e direitos fundamentais: diálogos contemporâneos. Salvador: JusPodivm, 2013. p. 621-657.

OLIVERIA, P. E. C. A proteção constitucional e internacional do direito à liberdade de religião. São Paulo: Verbatim, 2010.

ORO, A. P.; CARVALHO, E. T.; SCURO, J. O Sacrifício de animais nas religiões afro-brasileiras: uma polêmica recorrente no Rio Grande do Sul. Religião e Sociedade, Rio de Janeiro, v. 37, n. 2, p. 229-253, 2017. Disponível em: http://www.scielo.br/readcube/epdf.php?doi $=10.1590 / 0100=85872017-37 \mathrm{v} 2 \mathrm{nca} 09$ p \&pidS $0100-85872017000200229 \& p d f \_p a t h=r s / v 37 n 2 / 0100-8587$ rs-37-2-00229.pdf\&lang=pt. Acesso em: 20 set. 2018.

PASSALACQUA, G. P. Estado e religião na Constituição Brasileira de 1988 apartheid religioso: a Suprema Corte dos EUA e o caso Church of the Lukumi Babalu Aye v. City of Hialeah. Rio de Janeiro: PUC-RIO, 2006. Disponível em: http://www.puc-rio.br/pibic/relatorio_resumo2006/relatorio/CCS/Dir/DIR_09_Gabriela_Palhares\%20.pdf. Acesso em: 29 set. 2018.

PIRES, T. I. T. Liberdade de consciência, liberdade de crença e pluralismo político. Revista de Informação Legislativa, Brasília, DF, ano 49, n. 195, p. 53-63, jul./set. 2012. Disponível em: https://www2.senado.leg.br/bdsf/ bitstream/handle/id/496597/000966846.pdf?sequence=1. Acesso em: 28 set. 2018.

RIO GRANDE DO SUL. Assembleia Legislativa. Lei n. 11.915, de 21 de maio de 2003. Institui o Código Estadual de Proteção aos Animais, no âmbito do Estado do Rio Grande do Sul. Disponível em: http://lproweb. procempa.com.br/pmpa/prefpoa/seda/usu_doc/lei_estadual_11.915.pdf. Acesso em: 26 mar. 2020. 
RIO GRANDE DO SUL. Assembleia Legislativa. Lei n. 12.131, de 22 de julho de 2004. Acrescenta parágrafo único ao artigo $2^{\circ}$ da Lei n. 11.915, de 21 de maio de 2003, que institui o Código Estadual de Proteção aos Animais, no âmbito do Estado do Rio Grande do Sul. Disponível em: http:// www.al.rs.gov.br/filerepository/replegis/arquivos/12.131.pdf. Acesso em: 26 mar. 2020.

ROTHENBURG, W. C. Direitos fundamentais. Rio de Janeiro: Forense, 2014a.

ROTHENBURG, W. C. Religião como direito no Estado democrático laico. In: LAZARI, R. J. N.; BERNARDI, R.; LEAL, B. B. Liberdade religiosa no Estado Democrático de Direito: questões históricas, filosóficas, políticas e jurídicas. Rio de Janeiro: Lumen Juris, 2014 b.

TATUÍ. Câmara Municipal. Lei n. 4.977, de 27 de outubro de 2015. Proíbe sobre a utilização, mutilação e/ou o sacrifício de animais em rituais religiosos ou de qualquer outra natureza no Município de Tatuí e dá outras providências. Disponível em: https://consulta.siscam.com.br/camaratatui/ arquivo?Id=16080. Acesso em: 26 mar. 2020.

TEIXEIRA, M. A. D. Ejé Xororô - Ejé Unpá Ô: os rituais sacrificiais e o debate sobre o abate de animais nos cultos afro-diaspóricos. Tradição $e$ Identidades, 5 nov. 2015. Disponível em: http://bernalopesaymar.blogspot. com/2015/11/normal-0-21-false-false-false-pt-br-x.html. Acesso em: 6 set. 2018 .

VIDA, S. S. Sacrifício animal em rituais religiosos: liberdade de culto versus direito animal (parte 1). Revista Brasileira de Direito Animal (RBDA), Salvador, v. 2, n. 2, p. 289-305, jan./jun. 2007. Disponível em: https://portalseer.ufba.br/index.php/RBDA/article/view/10305/7364. Acesso em: 10 out. 2018.

VIOTTO, T. B. Biocentrismo: dignidade e direitos fundamentais dos animais sencientes. Dissertação (Mestrado) - Centro Universitário de Bauru, Bauru, 2016.

WEINGARTNER NETO, J. Comentários ao artigo $5^{\circ}$, VI, VII e VIII. In: CANOTILHO, J. J. G. et al. Comentários à Constituição do Brasil. 2. ed. São Paulo: Saraiva/Almedina, 2018. p. 264-272.

Artigo recebido em: 26/08/2019.

Artigo aceito em: 04/03/2020. 


\section{Como citar este artigo (ABNT):}

ROTHENBURG, W. C.; STROPPA, T. Sacrifício ritual e crueldade contra animais: um caso de sustentabilidade cultural. Veredas do Direito, Belo Horizonte, v. 17, n. 37, p. 295-322, jan.-abr. 2020. Disponível em: http:// revista.domhelder.edu.br/index.php/veredas/article/view/1626. Acesso em: dia mês. ano. 